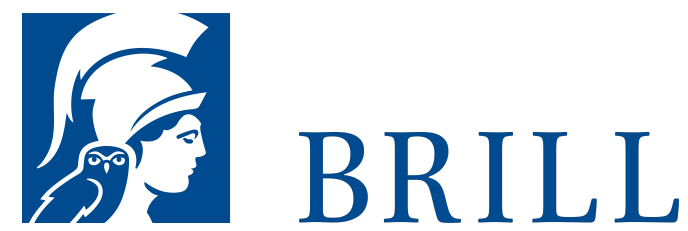

\title{
Prinzip, Erfahrung, Reflexion
}

Urteilskraft in der Angewandten Ethik

Author: Sabine Salloch

Das Vermögen zu urteilen gehört zu den grundlegenden menschlichen Fähigkeiten. Erst das Urteil ermöglicht uns die Orientierung in der Welt und den handelnden Umgang mit moralisch anspruchsvollen Situationen, die uns im Alltag, aber auch in der Wissenschaft und Berufspraxis begegnen. Der Abstand zwischen abstrakten ethischen Prinzipien und den empirisch komplexen Sachlagen des »wirklichen Lebens « ist oft groß. Praktische Urteilskraft stellt als Vermögen die Verbindung zwischen normativen Orientierungsmaßstäben und lebensweltlichen moralischen Herausforderungen her. Wie genau die Urteilskraft hierbei verfährt und worin der Anspruch auf eine intersubjektive Gültigkeit des moralischen Urteils begründet ist, liegt oftmals im Dunkeln. Unter Bezugnahme auf Kants Theorie der Reflexion unternimmt das Buch den Versuch, die »black box« praktischer Urteilskraft zu erhellen. Dabei wird die spezielle Situation Angewandter Ethik in den Blick genommen, die sich als praxisorientiertes Arbeitsfeld mit spezifischen Anforderungen konfrontiert sieht. Das Buch entwickelt ein eigenes Modell praktischer Urteilskraft für die Angewandte Ethik, das an einem medizinethischen Beispiel illustriert wird.

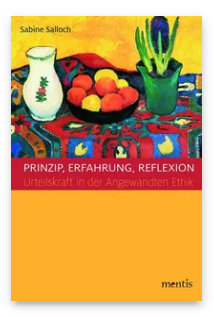

Pages: 341

Seiten

Language:

German

Subjects: 19th \& 2oth Century

Philosophy, Philosophy

Publisher: Brill | mentis

E-Book (PDF)

Released online: 16 Sep 2016

ISBN: $978-3-$ 95743-878-2 List price

Paperback

Publication date: 16 Sep 2016

ISBN: 978-395743-063-2

List price 
For more information see brill.com

Order information: Order online at brill.com +44330 333 0049 | customerservices@brill.com Submission information: brill.com/authors

Titles published by Brill | Fink, Brill | mentis or Brill | Schöningh: +49(o)715413279216| brill@brocom.de 